\title{
An overview of research into conservation practice effects on soil and water resources in the Upper Washita Basin, Oklahoma, United States
}

\author{
D.N. Moriasi, P.J. Starks, J.L. Steiner, X.C. Zhang, J.D. Garbrecht, and S. Glasgow
}

\begin{abstract}
The Fort Cobb Reservoir Experimental Watershed (FCREW) and Little Washita River Experimental Watershed (LWREW), located within the Upper Washita Basin (UWB) in Oklahoma, are part of the Agricultural Research Service (ARS) Benchmark Conservation Effects Assessment Project (CEAP)-Watershed Assessment Studies locations. The CEAP was created in 2003 by the USDA Natural Resources Conservation Service (NRCS) in partnership with USDA ARS and many other partners to quantify the environmental effects of conservation practices (CPs) and programs and to develop the science base for managing the agricultural landscape for environmental quality. The ultimate goal of this study was to present CPs that are expected to work at respective spatial scales, based on the findings of research that has been carried out in these CEAP and other watersheds within the UWB in the last 15 years. A summary of research findings indicates that the effects of CPs on soil and water resources were simulated at various spatial scales. At the large watershed scale, average annual suspended sediment yield at the $786 \mathrm{~km}^{2}\left(303 \mathrm{mi}^{2}\right)$ FCREW outlet was reduced by $86 \%$ based on multiple CPs implemented from the 1950s to 2008 by NRCS. Specific quantified effects of studied CPs are presented herein. With the exception of red cedar (Juniperus virginiana L.) removal, single CPs were expected to show improvement of soil and water resources in smaller-scale watersheds. Practices that are expected to improve soil and water resources include grassland conservation from red cedar encroachment (brush control), combined streambank stabilization practices, riparian and filter strip buffer practices, and conversion of cropped area to Bermuda grass (Cynodon dactylon [L.] Pers.).
\end{abstract}

Key words: climate-Conservation Effects Assessment Project (CEAP)-Fort Cobb Reservoir-Little Washita—North Canadian River-Oklahoma

The Fort Cobb Reservoir Experimental Watershed (FCREW) and Little Washita River Experimental Watershed (LWREW), located within the Upper Washita Basin (UWB) in Oklahoma, are part of the Agricultural Research Service (ARS) Benchmark Conservation Effects Assessment Project-Watershed Assessment Studies (CEAP-WAS) locations. The CEAP was established in 2003 by the USDA Natural Resources Conservation Service (NRCS) in partnership with USDA ARS and many other partners to quantify the environmental effects at the watershed scale of conservation practices (CPs) and programs and to develop the science base for managing and trophic level of the lake associated with seasonal phosphorus $(\mathrm{P})$ and nitrogen $(\mathrm{N})$ loads in some stream segments (Steiner et al. 2008). Several flood-retarding structures were constructed by NRCS in the LWREW from 1969 to 1982 having a design life of 50 years. Although the flood retarding aspect of these structures has been verified, these aging structures and those installed around the country need assessment in terms of current storage capacity and degree of sedimentation that has occurred over the years.

Several factors have contributed to the described soil and water resources concerns in these CEAP and nearby watersheds. These include land use change (Starks et al. 2014a), eastern red cedar (Juniperus virginiana L.) encroachment (Starks et al. 2014b), unstable stream channels (Simon and Klimetz 2008), and climate variability and projected intensification (Garbrecht et al. 2006). The FCREW and LWREW in the UWB, Oklahoma, differ from one another in terms of both their general agricultural uses and land cover types and dynamics (Starks et al. 2014a). Starks et al. (2014a) conducted a land cover study for these watersheds for the period 1974 to 2007. They found that the LWREW was stable in its land cover, which consisted of $12 \%$ trees, $15 \%$ cropland, $65 \%$ grassland, and $8 \%$ other. Land cover in the three main subwatersheds within the FCREW was found to consist of $5 \%$ trees, $47 \%$ cropland, $36 \%$ grassland, and $12 \%$ other. From $43 \%$ to $65 \%$ of the cropland category consisted of winter wheat (Triticum aestivum L.), depending upon year. Non-winter wheat cropland in any given year was a mix of corn (Zea mays), cotton (Gossypium hirsutum L.), peanuts (Arachis hypogaea L.), field peas (Pisum sativum), watermelons (Citrullus lanatus), peppers (Capsicum), and soybeans (Glycine max), among others. Moreover, the location, mix, and area devoted to a given crop (winter wheat included) varied from year to year.

Daniel N. Moriasi (corresponding author) is a hydrologist, Patrick J. Starks is a soil scientist, Xunchang (John) Zhang is a hydrologist, and Jurgen D. Garbrecht is a hydraulic engineer at the USDA Agricultural Research Service (ARS) Grazinglands Research Laboratory, El Reno, Oklahoma. Jean L. Steiner is an adjunct professor in the Agronomy Department, Kansas State University, Manhattan, Kansas. Steven Glasgow is state resource conservationist with the USDA Natural Resources Conservation Service, Stillwater, Oklahoma. 
Such land use changes have impacted soil and water resources due to changes in land management practices such as tillage and fertilizer applications and their corresponding timing relative to the climate.

The USDA NRCS, through the Environmental Quality Incentives Program (EQIP) commits large amounts of costshare funding for brush control and reducing encroachment of woody species into grasslands and rangelands. From 2007 to 2017, NRCS spent US $\$ 26,129,978$ for brush control on 277,123 ha $(684,786$ ac) in Oklahoma alone. Starks et al. (2014b) summarized the impacts of eastern red cedar on the ecosystem. This woody species is aggressively encroaching rangelands and grasslands in the Great Plains of the United States. McKinley et al. (2008) noted that red cedar had encroached upon about 7 million ha $(17$ million ac) of grassland in the eastern portion of the Great Plains. Red cedar has been shown to decrease forage availability (Bidwell and Mosely 1989), decrease plant and animal species diversity (Chapman et al. 2004; Coppedge et al. 2001), and increase fire hazard (Drake and Todd 2002). One of the lesser known impacts of red cedar encroachment is its impact on hydrology. Starks et al. (2014b) showed that red cedar canopies intercept from $27 \%$ to $39 \%$ of annual rainfall as one moves east to west across Oklahoma. Further, it was found that red cedars transpire about $12.4 \mathrm{~L} \mathrm{mo}^{-1} \mathrm{~kg}^{-1}(1.5$ gal $\mathrm{mo}^{-1} \mathrm{lb}^{-1}$ ) of dry aboveground mass. Thus, a red cedar of about $2.1 \mathrm{~m}(6.9 \mathrm{ft})$ in height (approximately $8.2 \mathrm{~kg}$ [18.1 lb] of above ground dry mass) would transpire approximately $101.0 \mathrm{~L} \mathrm{mo}^{-1}\left(26.7 \mathrm{gal} \mathrm{mo}^{-1}\right)$. Although not part of the CEAP watersheds within the Washita Basin, the nearby North Canadian River watershed (NCRW) is another site that is of concern where encroachment of invasive species such as red cedar into grasslands affect beef production as well as water resources (Starks et al. 2011, 2014b). Starks and Moriasi (2017) used these findings within the Soil and Water Assessment Tool (SWAT) model to assess red cedar encroachment on surface runoff and water supply (findings are described later herein).

In 2006, Simon and Klimetz (2008) performed a rapid geomorphic assessment study within the FCREW and LWREW to determine the condition of the stream channel network. Results indicated that unstable stream channels, especially in the FCREW, make a considerable contri- bution to suspended sediment loadings. Specifically, annual suspended sediment yield of the FCREW and LWREW exceeded the median value for stable streams by $7,410 \%$ and $2,120 \%$, respectively (Simon and Klimetz 2008). Wilson et al. (2008) found that during a small storm in the FCREW in 2006 about $50 \%$ of suspended sediment originated from unstable stream bank sources. Knowledge of sediment provenance such as gully, overland erosion, or stream bank erosion is critical for developing precision conservation plans to effectively control soil erosion and sediment delivery in a watershed. Zhang et al (2016a, 2016b) used a simple mixing model with cesium-137 $\left({ }^{137} \mathrm{Cs}\right)$ and composite fingerprints methods to apportion sediment sources between overland and gully erosion in the Bull Creek watershed $\left(16 \mathrm{~km}^{2}\left[6 \mathrm{mi}^{2}\right]\right)$, a tributary of the FCREW, and to estimate sedimentation rates in a reservoir within the watershed. The Bull Creek watershed occupies approximately $16 \mathrm{~km}^{2}$ with about $50 \%$ of the area being cultivated mainly for winter wheat and $45 \%$ in rangelands. Overall results from both approaches indicated that approximately $50 \%$ of fine sediments were from the gully banks, and the other half from overland flow. This result was consistent with that reported by Wilson et al. (2008).

These concerns are exacerbated by a climate that varies from season to season, year to year, decade to decade, and over longer periods. Garbrecht et al. (2006) found that precipitation variations lasting five or more years with predominantly above or below average annual precipitation are common in the FCREW long-term precipitation records, and referred to them as wet or dry periods. In a subsequent study, Garbrecht (2008) investigated the impacts of these persistent multiyear precipitation variations on the FCREW watershed runoff and sediment yield for the years 1940 to 2005. The study showed that runoff and estimated sediment yield were sensitive to persistent wet and dry periods. For the case at hand, a mean annual precipitation difference between wet and dry periods of $33 \%$ led to a $100 \%$ difference in runoff, which in turn led to a $183 \%$ difference in estimated sediment yield. Thus, small or moderate multiyear variations in precipitation can amplify into comparatively large watershed runoff and sediment yield variations. In carrying out climate scenario simulations, it is essential to remember that projected climate change contains several sources of error that lead to uncertainty in projected model outputs (Garbrecht et al. 2016). Awareness of these uncertainties is important when developing flexible and affordable conservation and adaptation measures that remain effective over the broad range of climate conditions.

Therefore, since the inception of CEAP, research has been conducted to test the effectiveness of CPs to address the improvement of soil and water resources. As part of this special issue, this paper presents a summary of studies related to placement and impacts of CPs based on the findings of the research that has been conducted in the FCREW, LWREW, and NCRW watersheds in the last 15 years. Specific objectives were to present the following: (1) common CPs that have been implemented over the years to protect soil and water resources, and (2) a summary of studies focused on identifying most vulnerable areas within the CEAP watersheds in the UWB and the impacts of the CPs implemented on soil and water resources.

\section{Materials and Methods}

Description of Watersheds. The watersheds included in this study are the FCREW, LWREW, and NCRW located in central Oklahoma (figure 1). Detailed descriptions of the watersheds are provided by Steiner et al. (2008, 2014), Starks et al. (2014a), Moriasi et al. (2014), and Starks and Moriasi (2017). Only a brief description of each watershed is provided below. A summary of major aspects of these watersheds is presented in table 1 .

The FCREW has a drainage area of 786 $\mathrm{km}^{2}$ (303 $\mathrm{mi}^{2}$ ) above the reservoir dam (Steiner et al.2014). Three major streams feed the Fort Cobb Reservoir located at the outlet of the watershed.These are Willow Creek, Lake Creek, and the combined Five Mile and Cobb Creek with the US Geological Survey (USGS) stream gauges located at the outlet of respective drainage areas. The drainage areas of the Cobb Creek, Lake Creek, and Willow Creek subwatersheds are $342 \mathrm{~km}^{2}$ (132 $\left.\mathrm{mi}^{2}\right), 154 \mathrm{~km}^{2}$ (59 $\left.\mathrm{mi}^{2}\right)$, and $75 \mathrm{~km}^{2}$ $\left(29 \mathrm{mi}^{2}\right)$, respectively. In the Cobb Creek, the soils are predominantly silt-textured with some fine sandy loam soils. Soil types vary from erodible fine sandy loams, highly erodible fine sandy loams, loamy soils, and moderately erodible silt loams (Steiner et al. 2014). The FCREW has mixed agricultural land use, including cropland, pasture and rangeland, forests and shrub land, water, and 


\section{Figure 1}

Geographical locations of the three watersheds and land use categories.

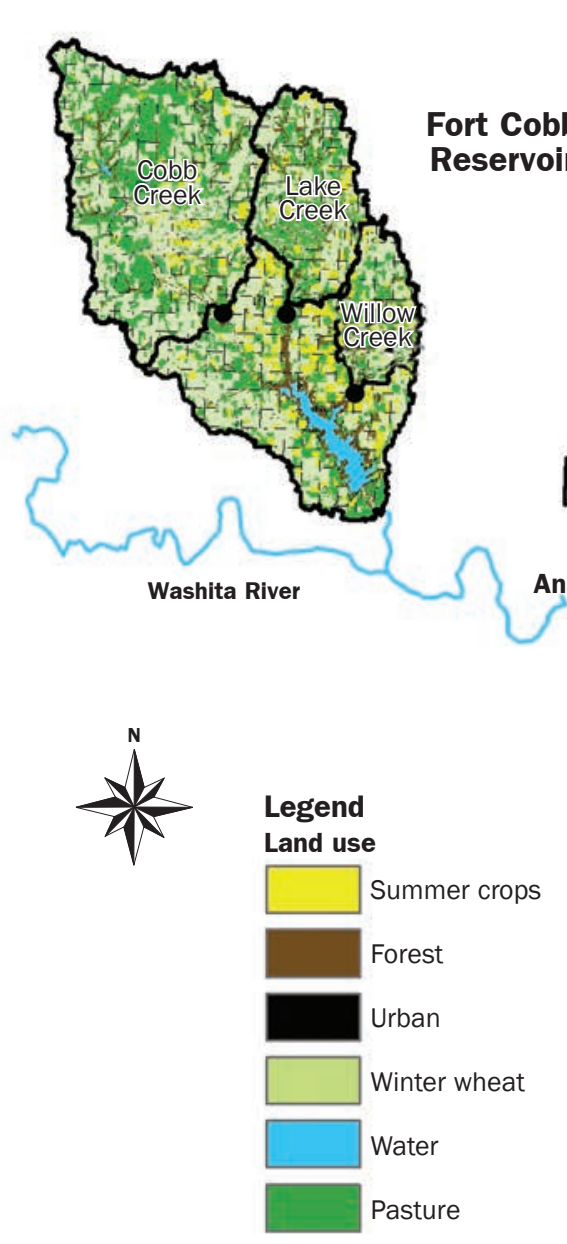

miscellaneous uses. The Fort Cobb Reservoir is on the Oklahoma state's list of impaired and threatened waterbodies known as 303(d) list due to excessive sedimentation and the trophic state of the lake (Steiner et al. 2008).

The LWREW covers an area of $610 \mathrm{~km}^{2}$ $\left(236 \mathrm{mi}^{2}\right)$.The main land use categories in the LWREW, which have stayed relatively constant over time, include grassland/rangeland/ shrubland, cropland (winter wheat and summer crops), forest, and roads/urban (Starks et al. 2014a). The predominant sand-textured soils cover the central part of the watershed, silt loam textured soils cover the western and northeastern parts of the watershed, and loam soils are randomly distributed throughout the watershed (Moriasi et al. 2014).

The NCRW study area is a reach on the North Canadian River, extending from Canton Lake to Lake Overholser, covers an area of $1,802 \mathrm{~km}^{2}\left(696 \mathrm{mi}^{2}\right)$, and consists of four nested subwatersheds (based on location of USGS stream gages) with drainage areas ranging from 581 to $1,802 \mathrm{~km}^{2}$ (224 to $696 \mathrm{mi}^{2}$ ). The soils within the study area vary from silty clay and silt loams to fine sandy soils (Starks and Moriasi 2017). The land use consists of pasture, winter wheat, summer crop, riparian forest, and red cedar. This reach is part of the Oklahoma City public water supply.

Analysis of the USDA NRCS State Soils Geographic (STATSGO) (USDA NRCS 1994) databases indicated that the predominant soil hydrologic group in all three watersheds is B, covering between $70 \%$ and $82 \%$ of the LWREW and FCREW drainage areas, respectively (table 1). As a result of the Flood Control Act of 1944 (PL-534) and the Watershed Protection and Flood Prevention Act of 1954 (PL-566) (Hanson et al. 2007; Hunt et al. 2011), the Washita River Basin in Oklahoma was one of eleven pilot watershed projects selected for construction of flood control reservoirs. Forty-five reservoirs were installed between 1969 and 1982 in the LWREW (Allen and Naney 1991), while 6 reservoirs and 2 large grade control structures in the FCREW constructed between 1956 and 1959 (Moriasi et al. 2014). These reservoirs were designed with a 50 -year lifespan based on the prevailing land use and land management and climate conditions years at the time. Although these reservoirs were constructed primarily for flood control, they also provide wildlife habitat, are source of water supply for livestock and municipalities, and provide recreational opportunities.

Implemented Conservation Practices and Summary of Findings of Conservation Effects Assessment Project Studies. USDA NRCS and the Oklahoma Conservation Commission have assisted farmers and ranchers with the implementation of CPs. Most of these CPs have been funded through conservation programs such as EQIP and the 319 nonpoint source management program. In this study, we present CPs that have been implemented by NRCS within the FCREW and LWREW since these two watersheds were designated 


\section{Table 1}

Summary description of major characteristics of watersheds studied.

\begin{tabular}{|c|c|c|c|}
\hline \multirow[b]{2}{*}{ Characteristic } & \multicolumn{3}{|l|}{ Watershed } \\
\hline & $\begin{array}{l}\text { Fort Cobb Reservoir } \\
\text { Experimental Watershed }\end{array}$ & $\begin{array}{l}\text { Little Washita River } \\
\text { Experimental Watershed }\end{array}$ & $\begin{array}{l}\text { North Canadian } \\
\text { River watershed }\end{array}$ \\
\hline Elevation (high - low; m) & $564-387$ & $489-314$ & $599-366$ \\
\hline $\begin{array}{l}\text { Major soil hydrologic group } \\
\text { (\% cover of total area) }\end{array}$ & B (82\%) & B (70\%) & B (45\%) \\
\hline Annual average rainfall (mm) & 724 & 711 & 810 \\
\hline Daily mean temperature $\left({ }^{\circ} \mathrm{C}\right)$ & 16 & 16 & 15 \\
\hline Number of reservoirs/dams & 6 & 45 & 2 \\
\hline Purpose of reservoirs & Flood control & Flood control & Municipal, recreational \\
\hline
\end{tabular}

CEAP watersheds based on the collaboration between the NRCS and ARS.

The implemented CPs presented are those that NRCS has identified as essential to protect soil and water resources in the CEAP and surrounding watersheds. This information also helps provide context of the studies by USDA ARS related to CEAP in these watersheds as well as identify possible future research needs discussed later herein. We performed a literature review of studies on impacts of land management and CPs on soil and water resources in the UWB since the inception of CEAP in 2003. The studies fall into two main areas: those that identify vulnerable areas for cost effective CP placement and those that quantify the impacts of CPs on soil and water resources. A brief summary of each study and the corresponding major findings are then presented. From these findings, we identify the studied CPs that show promise to protect soil and water resources within the study areas.

\section{Results and Discussion}

From 2003 to 2017, CPs implemented by NRCS within the FCREW and LWREW watersheds primarily focused on addressing soil erosion, soil health, water quality impairments from sediment and nutrients, grazing lands degradation from invasive species, and improper grazing management. The CPs were applied on more than 63,535 ha $(157,000 \mathrm{ac})$ split almost equally between cropland and grazing lands (range and pasture), with treatment on 31,407 and 32,168 ha $(77,609$ and $79,489 \mathrm{ac})$ of cropland and grazing land, respectively. Details of specific CPs implemented by USDA NRCS are presented in tables 2 and 3.

Conservation Practices Implemented in the Upper Washita Basin. The most common CPs applied in the FCREW and LREW are divided into two categories based on the land use and primary purpose and benefit. The first category are the CPs applied on cropland to control erosion (reduction in active erosion and sedimentation) and to improve water quality and soil health. The CPs applied in this category are presented in table 2. Most practices applied provide multiple benefits. These practices are applied either as stand-

Table 2

Soil erosion control, water quality, and soil health improvement conservation practices implemented by the USDA Natural Resources Conservation Service between 2003 and 2017.

\begin{tabular}{lccc}
\hline Conservation practice & Area (ha) & Length (m) & Number \\
\hline Conservation cover & 183.24 & - & - \\
Conservation crop rotation & $6,919.60$ & - & - \\
Contour farming & 756.36 & - & - \\
Cover crop & 117.12 & - & - \\
Critical area planting & 117.24 & - & - \\
Diversion & - & $77,489.6$ & - \\
Forage and biomass planting & $2,218.61$ & - & - \\
Grade stabilization structure & - & - & 41 \\
Grassed waterway & 35.29 & - & - \\
Nutrient management & $6,688.85$ & - & - \\
Range planting & 695.29 & - & - \\
Residue and tillage Management, no-till & $9,680.08$ & - & - \\
Residue and tillage Management, reduced till & $3,926.66$ & - & - \\
Residue management, mulch till & 384.29 & - & - \\
Terrace & - & $17,453.5$ & -
\end{tabular}

alone practices or as a system. For example, cropland fields where terraces were applied most likely also include grassed waterways to provide for stable outlets. Grassed waterways also include critical area plantings to provide adequate vegetation. Systems on cropland acres included residue management, crop rotations, and cover crops. Conversion to no-till was the most common residue management practice applied. Nutrient management practices consist of managing rates, timing, sources, and methods of application to minimize transport of nutrients to water bodies. Technologies such as grid soil sampling and precision application methods have 
Table 3

Degraded grassland improvement conservation practices implemented by the USDA Natural Resources Conservation Service between 2003 and 2017.

\begin{tabular}{lccc}
\hline Conservation practice & Area (ha) & Length (m) & Number \\
\hline Brush management & 814.11 & - & - \\
Fence & - & $2,8221.1$ & - \\
Livestock pipeline & - & $4,893.4$ & - \\
Prescribed grazing & $12,657.92$ & - & - \\
Pumping plant & - & - & 17 \\
Water well & - & - & 25 \\
Watering facility & - & - & 30
\end{tabular}

increased. Stand-alone practices may include grade stabilization structures installed to treat gully erosion in cropland and/or grazing and fields.Vegetation establishment practices, including forage and biomass planting and range planting, are common in converting eroding cropland acres to permanent vegetation, which is later managed as a forage for grazing or hay.

The second category of CPs are those applied to address degraded grazing lands (range/pasture). The CPs applied in this category are presented in table 3. Brush management applied in these watersheds primarily focused on eastern red cedar and some mesquite (Prosopis). The invasion and spread of these species degrade biodiversity, impact the water cycle, and decrease livestock forage. Adoption of prescribed grazing often includes ensuring proper stocking rates and addressing the intensity and frequency of grazing events, which have caused degradation including loss of desirable plant species/ diversity, loss of forage production, impacts on the water cycle, and in some cases, increases in erosion. Planning and implementation of prescribed grazing includes facilitating practices including fences and water systems (wells, pipelines, and tanks).

Studies on Identifying Vulnerable Areas under Prevailing Land Management and Climate. A summary of the studies to identify the vulnerable areas and impacts of CPs on soil and water resources is presented in table 4. Franklin et al. (2013) identified spatial patterns in $\mathrm{P}$ (soluble reactive $\mathrm{P}$ and bioavailable $\mathrm{P}$ ) associated with landscape metrics for the dry and wet streamflow regimes within the FCREW. In their study, spatial autocorrelation of $\mathrm{P}$ was evaluated using contiguous (side-by-side) and upstream (upstream: downstream) connectivity matrices. Stream grab samples were collected biweekly from January of 2005 through December of 2009 from 15 sites distributed throughout the FCREW and analyzed for P. Biogeophysical metrics were compiled for each contributing area and were partitioned based on association to $\mathrm{P}$ concentrations. Results indicated that lateral metrics or landscape characteristics (topography, soil, geology, or management) were better predictors for soluble reactive $\mathrm{P}$ than instream metrics (stream geomorphic stage or water chemistry). During the wet phase, lateral metrics indicative of rapid surface and subsurface water movement were associated with higher $\mathrm{P}$ stream concentrations than during the dry phase. This research demonstrated that it is possible to detect landscapes more vulnerable to $\mathrm{P}$ losses and/or pollutions in either drought or very wet periods.

Botero-Acosta et al. (2017) developed a method to identify areas along the riparian zone that are susceptible to erosion by integrating the watershed MIKE-SHE and river MIKE-11 models (Refsgaard and Storm 1995) and the habitat suitability model, MaxEnt (Elith et al. 2006). Botero-Acosta et al. (2017) applied this method in the 786 $\mathrm{km}^{2}$ (303 $\mathrm{mi}^{2}$ ) FCREW. The study findings showed that approximatively $80 \%$ of the riparian zone has up to $30 \%$ probability to experience lateral bank erosion greater than

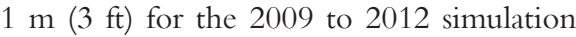
period. The most vulnerable areas for bank failure were found to be located at the upper riparian zone of the Cobb Creek and Lake Creek subwatersheds. The main waterways of these subwatersheds were also found to be vulnerable to streambank erosion. Being able to identify areas most prone to erosion enables targeted conservation and restoration efforts that lead to efficient use of resources.

Studies on Impacts of Land Management and Conservation Practices. A summary of the studies on the impacts of land management and CPs on soil and water resources are presented in table 4. Recently, Starks and Moriasi (2017) conducted a modeling study of the central portion of Oklahoma's $1,802 \mathrm{~km}^{2}\left(696 \mathrm{mi}^{2}\right)$ NCRW (figure 1). This section of the North Canadian River provides about 25\% of Oklahoma City's public water supply. Several modeling scenarios were implemented that varied red cedar encroachment from $0 \%$ to $80 \%$ in the basin's grassland areas. Reductions/increases in stream discharge were then evaluated at five locations within the study reach. Reductions in stream discharge with increasing red cedar encroachment were noted at all gaging locations in the model simulations, with more obvious reductions noted as one moved upstream. At a realistic encroachment of $20 \%$, the model simulations indicated a reduction of about $27 \%$ of Oklahoma City's current water demand. Reduction of the river basin's current $8 \%$ red cedar encroachment to $0 \%$ would increase water availability to Oklahoma City by $5 \%$ of current water demand.

Garbrecht and Starks (2009) and Zhang et al. (2016b) carried out separate studies that determined the impact of multiple CPs on soil and water resources. Garbrecht and Starks (2009) used discharge-sediment rating curves to generate data for analysis to determine the effects of the combined CPs implemented in the FCREW since the 1950s. The sediment-discharge rating curves were developed for the periods 1943 to 1948 and again in 2004 to 2007, which they referred to as preand postconservation periods, respectively. The 1940 to 1957 daily discharge records measured at the USGS gauge near the watershed and the two rating curves were used to generate daily suspended sediment yield before and after implementation of CPs. The estimated average annual suspended sediment yields at the watershed outlet were 760 $\mathrm{Mg} \mathrm{y}^{-1} \mathrm{~km}^{-2}\left(2,170 \mathrm{tn} \mathrm{yr}^{-1} \mathrm{mi}^{-2}\right)$ and 108 $\mathrm{Mg} \mathrm{y}^{-1} \mathrm{~km}^{-2}$ (308 tn $\mathrm{yr}^{-1} \mathrm{mi}^{-2}$ ) for the preand postconservation period, respectively. Garbrecht and Starks (2009) attributed the $86 \%$ reduction in suspended sediment yield to the cumulative effects of land use and management changes and the wide range of CPs implemented since the 1950s. Land use conversion was from cropland to range and pasture land, and soil CPs included conservation tillage, terracing of cropland, gully shaping, grade control structures, channel stabilization, sediment trapping by water impoundments, and county road surfacing.

In addition to utilizing the fallout radionuclides ${ }^{137} \mathrm{Cs}$ and excess lead-201 $\left({ }^{210} \mathrm{~Pb}\right)$ to determine the sediment sources of the reservoir located in the $15.6 \mathrm{~km}^{2}\left(6.0 \mathrm{mi}^{2}\right)$ Bull Creek watershed, a tributary of the 
Table 4

Summary of studies identifying vulnerable areas and studies on effects of conservation practices in the Upper Washita River.

\begin{tabular}{|c|c|c|c|c|}
\hline Watershed (study area) & $\begin{array}{l}\text { Drainage area } \\
\left(\mathbf{k m}^{2}\right)\end{array}$ & $\begin{array}{l}\text { Conservation practices } \\
\text { (CPs) studied }\end{array}$ & Major study findings & Reference \\
\hline \multicolumn{5}{|c|}{ Studies identifying vulnerable areas } \\
\hline \multirow[t]{2}{*}{$\begin{array}{l}\text { Fort Cobb Reservoir } \\
\text { Experimental Watershed }\end{array}$} & 786 & $\begin{array}{l}\text { Nutrient management: identify } \\
\text { landscapes more vulnerable to P } \\
\text { losses and/or pollutions during } \\
\text { dry and wet periods. }\end{array}$ & $\begin{array}{l}\text { Lateral metrics (topography, soil, geology, } \\
\text { management) better predicted soluble reactive } \\
\text { P than instream metrics (stream geomorphic } \\
\text { stage, water chemistry). During the wet phase, } \\
\text { lateral metrics indicative of rapid surface and } \\
\text { subsurface water movement were associated } \\
\text { with higher P stream concentrations than during } \\
\text { the dry phase. }\end{array}$ & $\begin{array}{l}\text { Franklin et al. } \\
\text { (2013) }\end{array}$ \\
\hline & & $\begin{array}{l}\text { Vulnerable riparian buffer areas } \\
\text { for targeted CP application. }\end{array}$ & $\begin{array}{l}\text { Eighty percent of the riparian zone has up to } \\
30 \% \text { probability to experience erosion greater } \\
\text { than } 1 \mathrm{~m} \text {. }\end{array}$ & $\begin{array}{l}\text { Botero-Acosta } \\
\text { et al. (2017) }\end{array}$ \\
\hline
\end{tabular}

Studies on effects of conservation practices

\begin{tabular}{|c|c|c|c|c|}
\hline $\begin{array}{l}\text { Little Washita River } \\
\text { Experimental Watershed }\end{array}$ & 786 & $\begin{array}{l}\text { Multiple CPs implemented since } \\
\text { 1950s: conversion from cropland } \\
\text { to range and pasture land, } \\
\text { conservation tillage, terracing of } \\
\text { cropland, gully shaping, grade } \\
\text { control structures, channel } \\
\text { stabilization, sediment trapping by } \\
\text { water impoundments, and county } \\
\text { road surfacing. }\end{array}$ & $\begin{array}{l}\text { Average annual suspended sediment yield at } \\
\text { the watershed outlet was reduced from } 760 \\
\text { to } 108 \mathrm{Mg}^{-1} \mathrm{~km}^{-2} \text { for the pre- and } \\
\text { postconservation period, respectively; } \\
86 \% \text { reduction. }\end{array}$ & $\begin{array}{l}\text { Garbrecht } \\
\text { and Starks (2009) }\end{array}$ \\
\hline $\begin{array}{l}\text { Fort Cobb Reservoir } \\
\text { Experimental Watershed } \\
\text { (Bull Creek subwatershed) }\end{array}$ & 16 & $\begin{array}{l}\text { Multiple CPs over the years: } \\
\text { construction of check dams, } \\
\text { installment of sloped terraces, } \\
\text { shift of cotton production to winter } \\
\text { wheat, adoption of conservation } \\
\text { tillage and no-till, and } \\
\text { implementation of conservation } \\
\text { reserve program over the years. }\end{array}$ & $\begin{array}{l}\text { The estimated soil erosion rate was } 29.0 \\
\text { Mg ha }^{-1} \mathrm{y}^{-1} \text { for } 1957 \text { to } 1963 \text { and } 6.8 \mathrm{Mg} \mathrm{ha}^{-1} \\
\mathrm{y}^{-1} \text { for } 1964 \text { to } 2003 ; 77 \% \text { reduction. }\end{array}$ & $\begin{array}{l}\text { Zhang et al. } \\
(2016 b)\end{array}$ \\
\hline $\begin{array}{l}\text { Fort Cobb Reservoir } \\
\text { Experimental Watershed } \\
\text { (Cobb Creek subwatershed) }\end{array}$ & 342 & $\begin{array}{l}\text { Simulated effects of riparian and } \\
\text { filter strip buffers. }\end{array}$ & $\begin{array}{l}\text { Application of Bermuda filter strip (BFS) along } \\
\text { cropland borders reduced the amount of } \\
\text { eroded overland sediment delivered into the } \\
\text { stream channel network by } 72 \% \text { reduction. } \\
\text { Application of riparian forest buffer (RF) and } \\
\text { combined RF and BFS reduced suspended } \\
\text { sediment at the subwatershed outlet by } 68 \% \\
\text { and } 73 \% \text {, respectively. }\end{array}$ & $\begin{array}{l}\text { Moriasi et al. } \\
(2011)\end{array}$ \\
\hline $\begin{array}{l}\text { Fort Cobb Reservoir } \\
\text { Experimental Watershed } \\
\text { (Five Mile Creek } \\
\text { subwatershed) }\end{array}$ & 110 & $\begin{array}{l}\text { Three stabilization practices were } \\
\text { analyzed for their effectiveness: } \\
\text { grade control, riprap toe, and } \\
\text { vegetation and bank grading with } \\
\text { both } 2: 1 \text { and } 3: 1 \text { bank slopes. } \\
\text { Simulated on } 10.25 \mathrm{~km} \text { reach. }\end{array}$ & $\begin{array}{l}\text { Incorporating multiple stabilization practices } \\
\text { simultaneously resulted in higher sediment load, } \\
\text { but also higher costs which were quantifiable } \\
\text { using the framework. Vegetation with } 2: 1 \text { bank } \\
\text { slopes was the most cost-effective stabilization } \\
\text { technique. }\end{array}$ & Enlow et al. (2018) \\
\hline
\end{tabular}

FCREW, Zhang et al. (2016b) used a modeling approach to estimate sedimentation rates in a reservoir within the watershed. Sedimentation rates in the reservoir during 1957 to 1963 , calculated based on the estimated sediment chronology, were three to five times those during 1964 to 2011 (Zhang et al. 2015). The mean sedimentation rates ranged from 6.2 to $12.7 \mathrm{~g} \mathrm{~cm}^{-2} \mathrm{y}^{-1}$ (0.09 to $\left.0.18 \mathrm{lb} \mathrm{in}^{-2} \mathrm{yr}^{-1}\right)$ during 1957 to 1963 and from 1.4 to $4.2 \mathrm{~g} \mathrm{~cm}^{-2} \mathrm{y}^{-1}$ (0.02 to $0.06 \mathrm{lb} \mathrm{in}^{-2}$ $\mathrm{yr}^{-1}$ ) during 1964 to 2011 . The sedimentation rates calculated with a hybrid constant-rateof-supply model clearly decreased from 1957 to 1963 , and then somewhat leveled off after
1963. The sediment mass in the reservoir was divided by drainage area and accumulation years to obtain sediment rate in tons per hectare per year, which was further corrected for a sediment delivery ratio of $42 \%$ to obtain soil erosion rate in tons per hectare per year. Results showed that the annual sediment yield of 1957 to 1963 was 4.3 times that of 1964 to 2003 , and so were the erosion rates. The estimated soil erosion rate was 29.0 $\mathrm{Mg} \mathrm{ha} \mathrm{y}^{-1} \mathrm{y}^{-1}$ (12.9 th $\left.\mathrm{ac}^{-1} \mathrm{yr}^{-1}\right)$ for 1957 to 1963 and $6.8 \mathrm{Mg} \mathrm{ha}^{-1} \mathrm{y}^{-1}\left(3.0 \mathrm{tn} \mathrm{ac}^{-1} \mathrm{yr}^{-1}\right)$ for 1964 to 2003. The erosion rate during 1957 to 1963 was twofold greater than the tolerable soil loss rate ( $\mathrm{T}$ value) of $10 \mathrm{Mg} \mathrm{ha}{ }^{-1}$ $\mathrm{y}^{-1}$ (4.5 $\left.\mathrm{tn} \mathrm{ac}^{-1} \mathrm{yr}^{-1}\right)$, while the rate during 1964 to 2003 was below the $\mathrm{T}$ value. The substantial reduction in soil erosion after 1964 was attributed to the extensive implementation of soil and water conservation measures including construction of several check dams, installment of sloped terraces, shift of cotton production to winter wheat, adoption of conservation tillage and no-till, and implementation of the Conservation Reserve Program over the years.

Earlier, the SWAT model (Arnold et al. 1998) was calibrated and validated for streamflow and suspended sediments in the $342 \mathrm{~km}^{2}$ (132 $\left.\mathrm{mi}^{2}\right)$ Cobb Creek subwater- 
Table 4 continued

\begin{tabular}{|c|c|c|c|c|}
\hline Watershed (study area) & $\begin{array}{l}\text { Drainage area } \\
\left(\mathbf{k m}^{2}\right)\end{array}$ & $\begin{array}{l}\text { Conservation practices } \\
\text { (CPs) studied }\end{array}$ & Major study findings & Reference \\
\hline $\begin{array}{l}\text { Fort Cobb Reservoir } \\
\text { Experimental Watershed } \\
\text { (Lake Creek subwatershed) }\end{array}$ & 154 & $\begin{array}{l}\text { Simulation of converting winter } \\
\text { wheat, sorghum-wheat, and } \\
\text { peanut-wheat cropped areas to } \\
\text { Bermuda grass at upper, middle, } \\
\text { and lower locations in the } \\
\text { subwatershed. }\end{array}$ & $\begin{array}{l}\text { A } 2.5 \% \text { level best management practice (BMP) } \\
\text { implementation in the upper portion of the } \\
\text { subwatershed, where topographic and soils } \\
\text { conditions most strongly influenced erosion } \\
\text { rates, reduced sediment by } 15.3 \%, 9.6 \% \text {, and } \\
7.1 \% \text { for wheat, sorghum-wheat, and } \\
\text { peanut-wheat, respectively. } \\
\text { The same BMP implementation at the } 2.5 \% \text { level } \\
\text { in the upper portion of the subwatershed } \\
\text { reduced total P by } 6.8 \%, 5.1 \% \text {, and } 2.0 \% \text { for } \\
\text { sorghum-wheat, peanut-wheat, and winter } \\
\text { wheat systems, respectively. } \\
\text { Unlike changes in sediment, the effect of BMP } \\
\text { location on reductions in P is nearly negligible. }\end{array}$ & $\begin{array}{l}\text { Van Liew et al. } \\
\text { (2005) } \\
\text { el }\end{array}$ \\
\hline $\begin{array}{l}\text { Fort Cobb Reservoir } \\
\text { Experimental Watershed } \\
\text { (Lake Creek subwatershed) }\end{array}$ & 154 & $\begin{array}{l}\text { Simulation of conversion of } \\
\text { cropland to pasture: impact on } \mathrm{N} \text {. }\end{array}$ & $\begin{array}{l}\text { Converting } 75 \% \text { and } 100 \% \text { of the cropland } \\
\text { ( 50\% of the total subwatershed area) to } \\
\text { pasture decreased total N load by } 12 \% \text { and } 31 \% \text {, } \\
\text { respectively, after taking into account } \\
\text { baseline uncertainty. } \\
\text { The most likely baseline uncertainty for this } \\
\text { study was } 10 \% \text { and } 38 \% \text { for streamflow and total } \\
\mathrm{N}, \text { respectively. This study result underscores } \\
\text { the importance of incorporating uncertainty in } \\
\text { interpreting the results of simulated impacts of } \\
\text { CPs on water resources. }\end{array}$ & Prada et al. (2017) \\
\hline $\begin{array}{l}\text { Little Washita River } \\
\text { Experimental Watershed } \\
\text { (Upper Portion of Watershed) }\end{array}$ & 160 & $\begin{array}{l}\text { Flood control structures - } \\
\text { reservoirs. }\end{array}$ & $\begin{array}{l}\text { On average, flood-control structures decreased } \\
\text { annual peak streamflow by } 31 \%, 31 \% \text {, and } 37 \% \\
\text { under dry, average, and wet climatic conditions, } \\
\text { respectively. }\end{array}$ & $\begin{array}{l}\text { Van Liew et al. } \\
(2003)\end{array}$ \\
\hline $\begin{array}{l}\text { Little Washita River } \\
\text { Experimental Watershed }\end{array}$ & 610 & $\begin{array}{l}\text { Flood control structures - } \\
\text { reservoirs. }\end{array}$ & $\begin{array}{l}\text { Reservoir lifespans ranged from } 45 \text { to } 118 \\
\text { years, with } 11 \text { of } 12 \text { reservoirs having a } \\
\text { lifespan greater than the design period of } 50 \\
\text { years. The higher projected lifespans could be } \\
\text { attributed to multiple CPs implemented over the } \\
\text { years through the NRCS programs. }\end{array}$ & $\begin{array}{l}\text { Moriasi et al. } \\
\text { (2018) }\end{array}$ \\
\hline
\end{tabular}

shed (CCSW) located within the FCREW (figure 1) and used to determine the impacts of riparian and filter strip buffers on water resources (Moriasi et al. 2011). The main land use categories in the CCSW include winter wheat (47.6\%) and grass (38.3\%) with peanut/cotton and other summer crops (6.5\%), forest $(3.2 \%)$, water $(0.4 \%)$, and urban/roads (3.8\%). In addition, the CCSW contains six USDA-funded flood-retarding structures installed from 1956 through 1959, the largest of which is Crowder Lake with a drainage area of approximately $70 \mathrm{~km}^{2}\left(27 \mathrm{mi}^{2}\right)$. The study showed that that a $10 \mathrm{~m}(33 \mathrm{ft})$ Bermuda grass (Cynodon dactylon [L.] Pers.) filter strip along cropland borders reduced the amount of eroded overland sediment delivered into the stream channel network by $72 \%$. Application of riparian forest buffer and combined riparian forest buffer and
Bermuda grass filter strip reduced suspended sediment at the subwatershed outlet by $68 \%$ and $73 \%$, respectively.

Enlow et al. (2018) developed a simulation framework to evaluate stabilization practices using hydraulic and sediment transport models, landowner preferences, construction costs, and effectiveness. Enlow et al. (2018) applied this framework on a $10.25 \mathrm{~km}(6.37$ mi) reach located in Five Mile Creek subwatershed within the FCREW to quantify the impacts of streambank stabilization techniques on sediment load reductions and the associated costs. Three stabilization practices selected for analysis included grade control, riprap toe, and vegetation and bank grading with both 2:1 and 3:1 bank slopes. Results indicated that incorporating multiple stabilization practices simultaneously resulted in higher sediment load reductions, but also higher costs, which were quantifiable using the framework. Therefore, it is essential to consider costs when deciding on CPs to apply. Vegetation with 2:1 bank slopes was the most cost-effective stabilization technique.

Van Liew et al. (2003) evaluated a 160 $\mathrm{km}^{2}\left(62 \mathrm{mi}^{2}\right)$ subwatershed of the LWREW using the SWAT model to determine the integrated effects of the flood retarding structures on flow characteristics and maximum daily flows under dry, average, and wet climatic conditions. The subwatershed contains 13 flood-control structures, which control $65 \%$ of the drainage area. Results showed that flood-control structures led to an average decrease in annual peak streamflow of about $31 \%, 31 \%$, and $37 \%$ under dry, average, and wet climatic conditions, respectively. The findings confirmed the importance of the 
flood control structures in reducing flooding and related property damage.

In a subsequent study, Moriasi et al. (2018) selected 12 reservoirs within the LWREW to determine volumetric reservoir sedimentation rates based on bathymetric survey and to identify the impacts of selected topographic features, land cover type, soil properties, and climate variables on reservoir sedimentation rates. The results indicated that the sedimentation rates normalized by reservoir drainage area ranged from 181 to $873 \mathrm{~m}^{-3} \mathrm{~km}^{-2} \mathrm{y}^{-1}$ (16,555 to $79,849 \mathrm{ft}^{-3} \mathrm{mi}^{-2}$ $\mathrm{yr}^{-1}$ ) while the reservoir lifespans ranged from 45 to 118 years. Eleven of the 12 reservoirs had a lifespan greater than the design period of 50 years. The higher projected lifespans could be attributed to implementation of CPs through several NRCS programs over the years (Garbrecht and Starks 2009; Zhang et al. 2016b). Results also indicated that it is possible to estimate sediment and flood storage capacity and projected lifespan of reservoirs using site-specific climate, soils, and topographic variables. This method provides a cost-effective approach that is transferrable to other areas to develop site-specific reservoir sedimentation equations.

In an earlier modeling study, Van Liew et al. (2005) used the SWAT model to simulate the impact of implementing selected best practices (BMPs) on surface runoff, sediment yields, and total $\mathrm{P}$ yields for the $136 \mathrm{~km}^{2}$ (50.51 $\mathrm{mi}^{2}$ ) Lake Creek watershed located within the FCREW. The studied BMPs included changing cultivated crops from winter wheat, sorghum (Sorghum bicolor)wheat, and peanut-wheat to Bermuda grass at upper, middle, and lower locations in the watershed. These BMPs were applied at three levels, converting $2.5 \%, 5.0 \%$, and $7.5 \%$ of the total watershed area. Changes in runoff, sediment, and $\mathrm{P}$ were simulated by the model for each of the three BMP levels. Study results showed that a $2.5 \%$ level BMP implementation in the upper portion of the subwatershed, where topographic and soils conditions most strongly influenced erosion rates, reduced sediment by $15.3 \%$, $9.6 \%$, and $7.1 \%$ for wheat, sorghum-wheat, and peanut-wheat, respectively. The same BMP implemented at the 2.5\% level in the upper portion of the subwatershed, reduced total $\mathrm{P}$ yields by $6.8 \%, 5.1 \%$, and $2.0 \%$ for sorghum-wheat, peanut-wheat, and winter wheat systems, respectively. Overall,Van Liew et al. (2005) determined that unlike changes in sediment, the effect of BMP location on reductions in $\mathrm{P}$ was negligible.

In a recent modeling study, Prada et al. (2017) used the Agricultural Policy/ Environmental eXtender (APEX) model (Williams et al. 2008) to determine the impacts of different land management practices on total monthly streamflow and total $\mathrm{N}$ in the $154 \mathrm{~km}^{2}\left(59.5 \mathrm{mi}^{2}\right)$ Lake Creek subwatershed located within the FCREW. Converting $75 \%$ and $100 \%$ of the cropland ( $~ 50 \%$ of the total subwatershed area) to pasture decreased total $\mathrm{N}$ load by $12 \%$ and $31 \%$, respectively, after taking into account baseline uncertainty. The baseline uncertainty was $10 \%$ and $38 \%$ for streamflow and total $\mathrm{N}$, respectively. This study underscores the importance of incorporating uncertainty in interpreting the results of simulated impacts of CPs on water resources.

Discussion of Studied Conservation Practices. Due to lack of control by ARS of the management and implemented CPs in the privately owned land within the UWB CEAP watersheds, the results of the effects of CPs reviewed in this study were based mainly on model simulations. Therefore, the simulated results are not presented as proof that these CPs have worked but rather that these practices are expected to work or improve soil and water quality. The CPs that have been studied in these watersheds, singly or in combination, include conversion from cropland to range and pasture land, conservation tillage, no-till, terracing of cropland, gully shaping, sediment trapping by water impoundments and flood control structures, county road surfacing, riparian buffers, filter strips, stream channel stabilization, and red cedar removal. A specific cropland to pastureland conversion study involved the conversion of areas covered by winter wheat, sorghum-wheat, and peanut-wheat to Bermuda grass to determine the impact on sediment and total P loads (Van Liew et al. 2005). Specific stream channel practices studied include grade control, riprap toe, and vegetation and bank grading with both $2: 1$ and 3:1 bank slopes (Enlow et al. 2018).

Based on the reported results of the effects of the CPs in the UWB, we make these general observations:

1. Implementation of multiple CPs over a long period of time is expected to lead to effective protection of soil and water resources, especially at the watershed scale (Garbrecht and Starks 2009; Zhang et al. 2016b; Moriasi et al. 2018). This is in line with how NRCS implements CPs as described earlier in this study.

2. The targeted placement of CPs, such as riparian buffers (Moriasi et al. 2011) or cropland conversion to grassland (Van Liew et al. 2005) in vulnerable areas, is a cost-effective approach as shown by Botero-Acosta et al. (2017).

3 . The greater the extent to which the CPs are applied within the study area, the greater the positive impact on soil and water resources (Van Liew et al. 2005; Prada et al. 2017; Starks and Moriasi et al. 2017).

Although the summary results presented in this paper are mainly based on modeling studies, it is a useful source information for NRCS personnel who seek to estimate/ assess the impacts of the CPs they continue to implement and to determine if they need to make any changes.

Discussion of Future Conservation Effects Assessment Project Research Needs in the Upper Washita Basin. Approximately $20 \%$ of the land in the FCREW is irrigated using water from the Rush Springs aquifer, mainly by center pivot irrigation systems (Steiner et al. 2014). However, detailed crop water use and water application efficiencies have not been quantified. Closing the irrigation water balance at field and basin scales is not possible without measured water budgets for irrigation applications in these watersheds. Accurate estimation of water use and determining major hydrologic and chemical transport processes is essential to improvement of hydrologic and water quality models to more accurately quantify the impacts of CPs. It can also help growers determine low-yielding areas and modify future irrigation and crop management plans. Therefore, future work seeks to (1) quantify the irrigation water budget for representative production fields to determine overall irrigation efficiency in the FCREW and (2) use the data obtained to develop and evaluate new irrigation algorithms in the integrated SWAT-MODFLOW (SWATmf) (Guzman et al. 2015) and APEX models to improve water budget predictions in order to increase the accuracy of water quantity and quality simulations. The APEX and SWAT models are especially important to NRCS programs because they are used for CEAP national assessments. APEX model is used to estimate field-level benefits of CPs 
(Johnson et al. 2015). The APEX outputs are integrated into SWAT to determine the benefits of CPs at the watershed and basin scale (Arnold et al. 2014). The CEAP-WAS findings including some from the FCREW and LWREW are continuously used to verify relative trends in results from the regional Cropland National Assessments.

As presented earlier in this paper, conversion to no-till and nutrient management are some of the common CPs that have been applied in cropped areas of the FCREW and LWREW. In a modeling study in the FCREW, Osei et al (2012) evaluated the effects of fuel costs and crop yield on farmlevel economics in no-till and conventional tillage systems for wheat production. The Farm-level Economic Model (Osei et al. 2000) was used along with the survey data from the FCREW, and a sensitivity analysis performed using plausible ranges in diesel prices, winter wheat grain yields, herbicide costs, labor wages, and farm size. Results indicated that no-till would be more profitable than conventional tillage or the current mix of tillage practices if winter wheat yields are identical across tillage systems. No-till would still be more profitable in most of the farms even if it results in a small yield penalty (about 5\%), and diesel prices are low. However, if the winter wheat grain yield penalty associated with no-till is greater than $10 \%$, no-till would no longer be as profitable as conventional tillage or the status quo, even at moderately high fuel prices. The study found that higher diesel prices, higher labor cost, lower herbicide costs, and smaller farm sizes are all economically advantageous to no-till. Whereas this study and its findings are useful because economics is one of the factors that play a major role in stakeholders' willingness to implement CPs, no reported studies have been carried out in the FCREW and LWREW to study the impacts of no-till and nutrient management CPs on soils and water resources. Therefore, future work will also seek to quantify the impacts of these two common CPs on soil and water resources. Finally, all the reviewed studies, except Van Liew et al. (2005) and Prada et al. (2017), focused on the effects of pertinent CPs on hydrology and sediments. Therefore, there is also a need for more studies to quantify the impacts of the studied CPs on nutrients where appropriate.

\section{Summary and Conclusions}

In this long-term CEAP watershed research, we have identified CPs that have worked and the scale at which they have worked, based on the results of the research studies that have been carried out in the last 15 years. In general, management practices impact soil and vegetation over years to decades; soil and vegetation properties influence hydrologic processes; and hydrology influences the fate and transport of nutrients, chemicals, and organisms at the field and watershed scales. Most of the studies in these watersheds were based on model simulations that were possible due to the rich long-term database in the watersheds. Essential take home messages from these studies are summarized herein. It is recommended to incorporate baseline uncertainty in modeling studies to realistically quantify the impacts of CPs on productivity and environment in order to determine best ones. The implementation of multiple CPs over the years has led to significant reduction in soil erosion and suspended sediment yield leading to longer lifespans for flood control reservoirs. Approximatively $80 \%$ of the riparian zone in the FCREW has up to $30 \%$ probability to experience lateral streambank erosion greater than $1 \mathrm{~m}(3 \mathrm{ft})$ during the 2009 to 2012 simulation period. However, cost-effective targeted riparian and filter strip buffer practices were simulated to significantly reduce suspended sediment yield at the CCSW within the FCREW. In addition, incorporating multiple stabilization practices simultaneously can lead to high sediment load reductions. With respect to nutrients, it is possible to detect landscapes more vulnerable to $\mathrm{P}$ losses and/or pollution in either drought or very wet periods and conversion of cropped area to grassland can lead to modest reductions in total $\mathrm{P}$ and total N.

Overall, several prior studies indicate that CPs were effective at conserving soil and water resources at various spatial scales. Average annual suspended sediment yield at the $786 \mathrm{~km}^{2}\left(303 \mathrm{mi}^{2}\right)$ FCREW outlet was reduced by $86 \%$ based on multiple CPs implemented over decades. The studied CPs that are expected to protect the soil and water resources in these watersheds include grassland conservation through red cedar brush control, combined streambank stabilization practices, riparian and filter strip buffer practices, and conversion of cropped area into Bermuda grass.

\section{Acknowledgements}

This research and assessment was supported by the USDA Natural Resources Conservation Service Conservation Effects Assessment Project Watershed Assessment Studies and Agricultural Research Service National Program 211.

\section{Disclaimer}

The findings and conclusions in this publication are those of the author(s) and should not be construed to represent any official USDA determination or policy.

\section{References}

Allen, P.B., and J.W. Naney. 1991. Hydrology of the Little Washita River watershed, Oklahoma, ARS-90, 74. Washington, DC: USDA Agricultural Research Service. Arnold, J.G., R.D. Harmel, M.V. Johnson, R. Bingner, T.C. Strickland, M. Walbridge, C. Santhi, M. DiLuzio, and X. Wang. 2014. Impact of the Agricultural Research Service watershed assessment studies on the conservation effects assessment project cropland national assessment. Journal of Soil and Water Conservation 69(5):137A-144A, https://doi.org/10.2489/jswc.69.5.137A.

Arnold, J.G., R. Srinivisan, R.S. Muttiah, and P.M. Allen. 1998. Large-area hydrologic modeling and assessment: Part I. Model development. Journal of American Water Resources Association 34:73-89.

Bidwell, T.G., and M.E. Mosely. 1989. Eastern Red Cedar: Oklahoma's centennial brush problem. Circular E-892. Stillwater, OK: USDA Soil Conservation Service and Oklahoma State University.

Botero-Acosta, A., M.L. Chu, J.A. Guzman, P. Starks, and D. Moriasi. 2017. Riparian erosion suitability model based on environmental features. Journal of Environmental Management 203:592-602.

Chapman, R.N., D.M. Engle, R.E. Masters, and D.M. Leslie Jr. 2004. Tree invasion constrains the influence of herbaceous structure in grassland bird habitats. Ecoscience 11:55-63. https://doi.org/10.1080/119568 60.2004.11682809.

Coppedge, B.R., D.M. Engle, R.E. Masters, and M.S. Gregory. 2001. Avian response to landscape change in fragmented Southern Great Plains grasslands. Ecological Applications 11(1):47-59.

Drake, B., and P. Todd. 2002. A Strategy for Control and Utilization of Invasive Juniper Species in Oklahoma. Oklahoma City: Oklahoma Department of Agriculture, Food and Forestry.

Duriancik, L.F., D.A. Bucks, J.P. Dobrowolski, T. Drewes, S.D. Eckles, L. Jolley, R.L. Kellogg, D. Lund, J.R. Makuch, M.P. O'Neill, C.A. Rewa, M.R. Walbridge, R. Parry, and M.A. Weltz. 2008. The first five years of the Conservation Effects Assessment Project. Journal of Soil and Water Conservation 63(6):185A-197A, doi:10.2489/jswc.63.6.185A.

Elith, J., C.H. Graham, R.P. Anderson, M. Dudik, and S. Ferrier. 2006. Novel methods improve predictions of 
species' distributions from occurrence data. Ecography 29:129-151.

Enlow, K.H., G.A. Fox., T.A. Boyer, A. Stoecker, D.E. Storm, P. Starks, and L. Guertault. 2018. A modeling framework for evaluating streambank stabilization practices for reach-scale sediment reduction. Environmental Modelling and Software 100:201-212.

Franklin, D.H., J.L. Steiner, S.E. Duke, D.N. Moriasi, and P.J. Starks. 2013. Spatial considerations in wet and dry periods for phosphorus in streams of the Fort Cobb watershed, USA. Journal of the American Water Resources Association 49(4):908-922.

Garbrecht, J.D. 2008. Multi-year precipitation variations and watershed sediment yield in a CEAP benchmark watershed. Journal of Soil and Water Conservation 63(2):70-76

Garbrecht, J.D., M.A. Nearing, X.C. Zhang, and J.L Steiner 2016. Uncertainty of climate change impacts on soil erosion from cropland in Central Oklahoma. Applied Engineering in Agriculture 32(6):823-836.

Garbrecht, J.D., and P.J. Starks. 2009. Watershed sediment yield reduction through soil conservation in a westcentral Oklahoma watershed. Ecohydrology 2:313-320.

Garbrecht, J.D., P.J. Starks, and J.L. Steiner. 2006. The under-appreciated climate factor in the Conservation Effects Assessment Project. Journal of Soil and Water Conservation 61(4):110A-112A

Guzman, J.A., D.N. Moriasi, P.H. Gowda, J.L. Steiner, J.G. Arnold, R. Srinivasan, and P.J. Starks. 2015. A fully integrated SWAT-MODFLOW hydrologic model. Environmental Modelling \& Software 73:103-116, doi:10.1016/j.envsoft.2015.08.011

Hanson, G.J., L. Caldwell, M. Lobrecht, D. McCook, S.L. Hunt, and D. Temple. 2007. A look at the engineering challenges of the USDA Small Watershed Program. Centennial Edition Transactions of the ASABE 50(5):1677-1682, doi: 10.13031/2013.23959.

Hunt, S., G.J. Hanson, D.M. Temple, and L. Caldwell. 2011. The importance of the USDA Small Watershed Program to the rural United States. Water Resources Impact 13(6):9-11.

Johnson, M.V.V., M.L. Norfleet, J.D. Atwood, K.D. Behrman, J.R. Kiniry,J.G.Arnold, M.J.White, and J.Williams. 2015 The Conservation Effects Assessment Project (CEAP): A national scale natural resources and conservation needs assessment and decision support tool. IOP Conference Series. Earth and Environmental Science 25, doi: 10.1088/1755-1315/25/1/012012.

Mausbach, M.J., and A.R. Dedrick. 2004. The length we go-measuring environmental benefits of conservation practices. Journal of Soil and Water Conservation 59(5):96A-103A.

McKinley, D.C., M.D., Norris, J.J. Blair, and L.C. Johnson. 2008. Altered ecosystem processes as a consequence of Juniperus virginia L. encroachment into North American tallgrass prairie. Ecological Studies 196:170-187.
Moriasi, D.N., P.J. Starks, J.A. Guzman, J.G. Garbrecht, J.L. Steiner, J.C. Stoner, P.B. Allen, and J.W. Naney. 2014. Upper Washita River Experimental Watersheds: Reservoir, groundwater, and stream flow data. Journal of Environmental Quality 43:1262-1272, doi:10.2134/ jeq2013.08.0329.

Moriasi, D.N., J.L. Steiner, and J.G. Arnold. 2011. Sediment measurement and transport modeling: Impact of riparian and filter strip buffers. Journal of Environmental Quality 40:807-814.

Moriasi, D.N, J.L. Steiner, S.E. Duke, P.J. Starks, and A.J. Verser. 2018. Reservoir sedimentation rates in the Little Washita River Experimental Watershed, Oklahoma: Measurement and controlling factors. Journal of the American Water Resources Association, doi:10.1111/1752-1688.12658

Osei, E., P.W. Gassman, and A. Saleh. 2000. Livestock and the environment: Economic and environmental modeling using CEEOT. Report No. PR0002. Stephenville, TX Texas Institute for Applied Environmental Research, Tarleton State University.

Osei, E., D.N. Moriasi, J.L. Steiner, P.J. Starks, and A. Saleh. 2012. Farm-level economic impact of no-till farming in the Fort Cobb Reservoir watershed. Journal of Soil and Water Conservation 67(2):75-86, doi:10.2489/ jswc.67.2.75.

Prada, A.F., M.L. Chu, J.A. Guzman, and D.N. Moriasi. 2017. Evaluating the impacts of agricultural land management practices on water quality: A probabilistic hydrologic modeling approach. Journal of Environmental Management 193:512-523.

Refsgaard,J. C., and B. Storm. 1995. MIKE SHE. In Computer Models of Watershed Hydrology, ed. V. Singh, 809-846. Highland Ranch, CO: Water Resources Publication.

Simon, A., and L. Klimetz. 2008. Relative magnitudes and sources of sediment in benchmark watersheds of the Conservation Effects Assessment Project. Journal of Soil and Water Conservation 63(6):504-522, doi:10.2489/ jswc.63.6.504.

Starks, P.J., and D.N. Moriasi. 2017. Impact of Eastern redcedar encroachment on stream discharge in the North Canadian River basin. Journal of Soil and Water Conservation 72(1):12-25, doi:10.2489/jswc.72.1.12.

Starks, P.J., J.L. Steiner, and A.J. Stern. 2014a. Upper Washita River experimental watersheds: Land cover datasets (1974-2007) for two southwestern Oklahoma watersheds. Journal of Environmental Quality 43:1310-1318.

Starks, P.J., B.C. Venuto, J.A. Eckroat, and T. Lucas. 2011 Measuring Eastern redcedar (Juniperus virginiana L.) mass with the use of satellite imagery. Rangeland Ecology and Management 64:178-186.

Starks, P.J., B.C. Venuto, W.A. Dugas, and J. Kiniry. 2014b. Measurements of canopy interception and transpiration of Eastern red cedar grown in open environments. Environment and Natural Resources Research 4(3):103-122
Steiner, J.L., P.J. Starks, J.A. Daniel, J.D. Garbrecht, D. Moriasi, S. McIntyre, and J.-S. Chen. 2008. Environmental effects of agricultural conservation: A framework for research in two watersheds in Oklahoma's upper Washita River basin. Journal of Soil and Water Conservation 63(6):443452, doi:10.2489/jswc.63.6.443.

Steiner, J.L., P.J. Starks, J.D. Garbrecht, D.N. Moriasi, J.X. Zhang, J.M. Schneider, J.A. Guzman, and E. Osei 2014. Long-term environmental research: The Upper Washita River Experimental Watersheds, Oklahoma, USA. Journal of Environmental Quality 43(4):1227-38, doi:10.2134/jeq2014.05.0229.

USDA NRCS (Natural Resources Conservation Service). 1994. State Soil Geographic (STATSGO) Data Base. Fort Worth,TX: USDA Natural Resources Conservation Service. http://water.usgs.gov/lookup/getspatial?ussoils.

Van Liew, M.W., J.A. Daniel, and J.G. Arnold. 2005. Downstream response of runoff, sediment, and phosphorous to spatial variations in conservation practice implementation. In Proceedings of the 2005 World Water and Environmental Resources Congress. EWRI 2005: Impacts of Global Climate Change.

Van Liew, M.W., J.D. Garbrecht, and J.G. Arnold. 2003 Simulation of the impacts of flood retarding structures on streamflow for a watershed in southwestern Oklahoma under dry, average, and wet climatic conditions. Journal of Soil and Water Conservation 58(6):340-348.

Williams, J.R., R.C. Izaurralde, and E.M. Steglich. 2008. Agricultural Policy/Environmental eXtender model theoretical documentation version 0604. BREC Report \#2008-17. Temple, TX: AgriLife Research, Texas A\&M. Blackland Research and Extension Center. http://epicapex.tamu.edu/files/2013/02/the-apextheoretical-documentation.pdf.

Wilson, C.G., R.A. Kuhnle, D.D. Bosch, J.L. Steiner, P.J. Starks, M.D. Tomer, and G.V.Wilson. 2008. Quantifying relative contributions from sediment sources in Conservation Effects Assessment Project watersheds. Journal of Soil and Water Conservation 63(6):523-532, doi:10.2489/jswc.63.6.523

Zhang, X.C., B.L. Liu, B. Liu, and G.H. Zhang. 2016a. Quantifying sediment provenance using multiple composite fingerprints in a small watershed in Oklahoma Journal of Environmental Quality 45:1296-1302.

Zhang, X.C., G.H. Zhang, J.D. Garbrecht, and J.L. Steiner. 2015. Dating sediment in a fast sedimentation reservoir using cesium-137 and lead-210. Soil Science Society of America Journal 79:948-956, doi:10.2136/ sssaj2015.01.0021

Zhang, X.C., G.H. Zhang, B.L. Liu, and B. Liu. 2016b. Using cesium-137 to quantify sediment source contribution and uncertainty in a small watershed. Catena 140:116124, doi:10.1016/j.catena.2016.01.021. 